\section{A MAGYARORSZÁGI LAKÁSBIZTOSITTÁSI PIAC HELYZETE ÉS ÚJ KIHÍVÁSAI}

Deliága Judit (épitészmérnök, Allianz Hungária Zrt. lakossági vagyon termék-és portfóliómenedzsment csoportvezetö, Mabisz Lakás-és Kisvállalkozás Biztositási Bizottság elnök)

\section{ÖSSZEFOGLALÓ}

A cikkben áttekintem a magyarországi lakáspiaci helyzetet, melynek trendjeit követi a lakásbiztosítási piac is, így az ingatlanpiaci várakozások jó előrejelzők lehetnek a lakásbiztosítások piacának várható alakulására vonatkozóan.

A KSH lakásfelmérés eredményeire támaszkodva összehasonlítom a lakók szubjektív megítélése alapján feltárt épületminőségi jellemzőket a biztosítók kártapasztalatai alapján szükségesnek ítélt felújításokkal.

Végezetül áttekintést adok a digitalizáció és insurtech fejlesztések kihívásairól a lakásbiztosítások specialitásaira koncentrálva.

\section{SUMMARY}

In this article I review the situation of the Hungarian housing market and its trends. In this respect the changes of the real estate market can be also predicted.

Based on the survey of KSH (Hungarian Central Statistical Office), I compare the building qualities given by the dwellers with the renovations deriving from the claims in the insurance companies.

Finally, I outline the challenges of digitalization and insurtech developments focusing on the features of the household insurance.

Kulcsszavak: lakásbiztosítás, lakáspiac

Key words: home insurance, housing market

JEL: G22, O18

DOI: $10.18530 / \mathrm{BK} .2017 .2 .60$

http://dx.doi.org/1018530/BK.2017.2.60

\section{Lakáspiaci helyzetkép}

A magyarországi lakásbiztosítási piac alakulása szorosan követi a lakáspiaci változásokat. Az önkormányzati lakások rendszerváltás után lezajlott privatizációját követően a 90-es évek visszaesést hoztak a lakásépítésekben - átmeneti fellendülést csak a „szocpol” politika jelentett az évtized közepén -, majd 2001-től az állami támogatású lakáshitelezés és a devizahitelezés felfutása eredményezett jelentős fellendülést. Ez a fellendülés együtt járt a lakásbiztosítások számának emelkedésével is. A hazai lakáspiaci tranzakciók és az épített lakások száma a 2000-es évek első feléhez képest közel a harmadára esett vissza a gazdasági recesszió éveiben, aminek következtében a lakásbiztosítási piac 2002-től megfigyelhető növekedése - mind darabszám, mind díjbevétel tekintetében - 2011-re leállt. Az egyéni lakásbiztosítások darabszáma a 2010es legmagasabb szinthez képest 4 év alatt 93 ezer darab szerződéssel csökkent.

2015-ben a lakásépítési engedélyek száma ismét emelkedni kezdett, amit segített a kamatkiadások folyamatos csökkenése, valamint a lakosság jövedelmi helyzetével kapcsolatos optimizmus. A hiteltörlesztések következtében a lakosság GDP-arányos eladósodottsága jelentősen csökkent, és a banki oldalon ismét fokozatosan erősödni kezdett a lakáshitelek iránti kereslet. Az ingatlanpiacon mind az új, mind a használt lakások ára dinamikus emelkedésnek indult, ami - a kereslet növekedése mellett - egyre inkább kifizetődővé tette az új projekteket. A 2015 végén bejelentett otthontámogatási program - elsősorban az áfa-kedvezmények és a CSOK - 2016-2017-re érezhető javulást hozott a lakásszektorban.

A KSH adatai szerint 2016-ban 9994 új lakás épült, ez 31 százalékkal haladta meg az egy évvel korábbi számokat (1. ábra). A lakásépítések növekedése eltérő volt az egyes településtípusok tekintetében. Bár valamennyi esetében elmondható, hogy nőtt az épített lakások száma, az átlagosnál nagyobb mértékủ emelkedés Budapesten (44\%) és a megyei jogú városokban (49\%) történt. Az építési engedélyek száma a lakásépítések erős felfutását jelzi: a kiadott lakásépítési engedélyek és bejelentések száma együtt 31559 volt, ami országosan több mint két és félszerese, ezen belül Budapesten közel háromszorosa az előző évinek.

A lakásépítések fellendülése, az új lakások iránti kereslet és az új lakások árának növekedése felfelé húzta a használtlakás-tranzakciókat is. A lakásbiztosítások számának növekedése erösen összefügg a lakáshitelezés fellendülésével, amire egyrészt a lakásépítések darabszámának, másrészt a használt lakások adásvételének növekedése hat. A befektetési célú vásárlások mellett ezen a területen is aktivizálódott a piac, a 2015. évi 134 ezres tranzakciószám 2016-ra már meghaladta a 150 ezret, és a következő években az elemzők arra számítanak, hogy az éves forgalom a válság előtti évek átlagának tekinthető 170-190 ezer darab körüli szintre fog beállni.

A lakásbiztosítások számának növekedése tekintetében ezek az elörejelzések bizakodásra adnak okot, de a 2015-től elkezdődött enyhe növekedés mellett évekbe telhet, míg a lakásbiztosítási szerződések száma ismét eléri a válság előtti szintet. Sajnálatos módon évek óta nem állnak rendelkezésre a lakásbiztosítási piac pontosabb elemzését lehetővé tevő adatok. 2016-tól a Szolvencia II szerinti MNB adatszolgáltatás „Lakossági vagyonbiztosítás” soraiból némileg képet kaphatunk a szektor helyzetéről, de nem teszi lehetővé a tisztánlátást, hogy ezekben a 
sorokban együtt jelennek meg a lakás- és társasház-biztosítások adatai, és az új adatok nem vethetők össze a korábbi évek más struktúrában gyüjtött adataival.

1. ábra: Lakásépítési engedélyek és épített lakások száma (évente, darab)

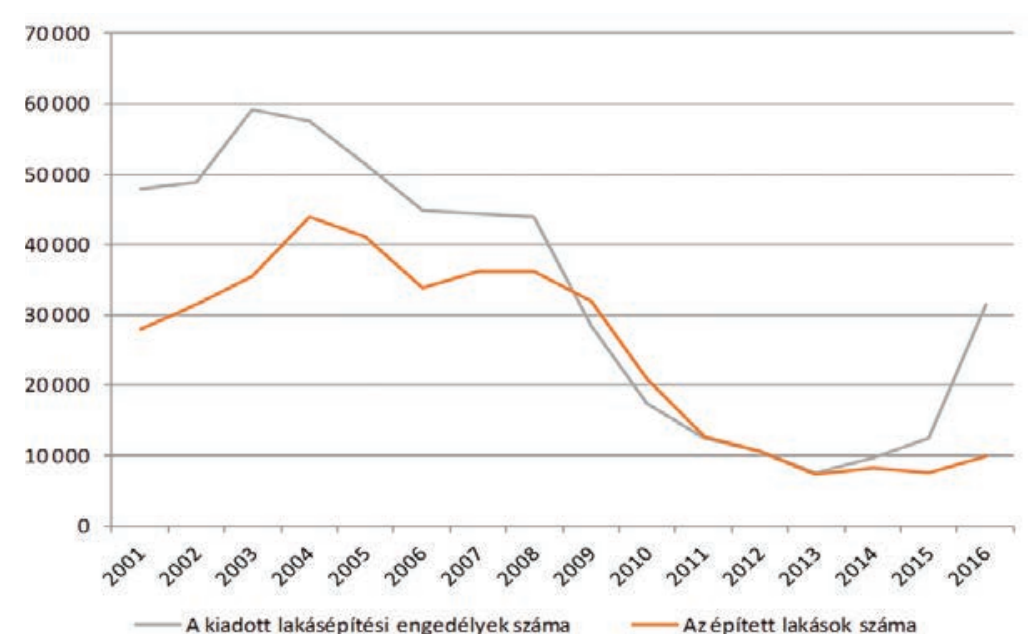

Forrás: KSH

\section{Miben élünk? Mit biztosítunk?}

A lakásépítésekre elsősorban nem a magyarországi lakásszám növelése, hanem a lakásállomány minőségi megújítása miatt van szükség. A jelenlegi ütemet tartva 400 évbe telne a lakásállományunk megújulása. Évente mintegy 40 ezer darab megépült lakásra lenne szükség egy 100 éves megújulási ciklushoz. Ez mutatja egyúttal, hogy az új építések mellett a felújítások szintén fontosak.

\section{A lakásállomány minősége a lakásbiztosítások \\ kockázata szempontjából kiemelt tényező.}

A lakásállomány minősége a lakásbiztosítások kockázata szempontjából kiemelt tényező. Sajnos ebben a tekintetben erős a lemaradásunk Nyugat-Európához képest. Magyarországon a lakosság több mint 25 százaléka olyan lakóingatlanban él, ahol nedvesek a falak és a padló, szivárog a tetőn a víz, vagy elkorhadtak a nyílászárók.

A KSH 2015. október-novemberi lakásfelmérése szerint a magyarországi lakóépületek száma közel 2,7 millióra tehető. A lakóépületek túlnyomó többsége 1-3 lakásos családi ház. A lakások száma 4,4 millió, ezek 61 százaléka van 1-3 lakásos épületben, az összes lakás 39 százaléka pedig 4 vagy többlakásos épületekben található. Mintegy
1 millió lakás van nagyméretű, 25 vagy több lakást tartalmazó épületben, amelyek főleg lakótelepeken találhatók.

A lakóépületek közel háromnegyede téglából, 21 százalékuk vályogból épült. Magas a vályogházak aránya az Alföldön, amelynek dél-alföldi területein további kockázatot jelent, hogy jelentős részük alapozás nélkül épült.

A magyar lakásállomány 19 százaléka 1945 előtt, 65 százaléka 1945-1990 között épült. A városi lakásállomány jelentős része nem szerves fejlődés útján jött létre: sok lakás régi villaházak megosztásának, a polgári lakások felszabdalásának, illetve a panelépítési dömpingnek az eredménye. A rendszerváltást követően privatizált bérlakások állaga tovább romlott, a tulajdonosok sok helyen nem tudták megszervezni a felújitást. Az újonnan épített lakásoknak köszönhetően ebben az időszakban a lakásállomány 16 százalékkal bővült. Azonban az új építésű lakásokkal kapcsolatban is kialakult egyfajta bizalmatlanság, az eltűnő projektcégek, nem érvényesíthető garanciális igények, a minőségi helyett a minél olcsóbb építőanyag választása közhelyek lettek.

2015-ben a lakások kevesebb mint 40 százalékában voltak a lakók maradéktalanul elégedettek az épület minőségével. A legjobb műszaki állapotban a lakók válaszai alapján a többszintes családi házak és a zöldövezeti társasházak voltak, míg a beavatkozást igénylő épületek aránya a városi bérházak és a hagyományos építésü parasztházak között a legmagasabb. Az épületek minőségét illetően a legtöbb lakó az épületek állagával és hőszigetelésével kapcsolatos problémát fogalmazott meg (2.ábra).

2. ábra: Lakások az épület állapota és a 2005 óta végzett felújítások szerint, 2015 [\%]

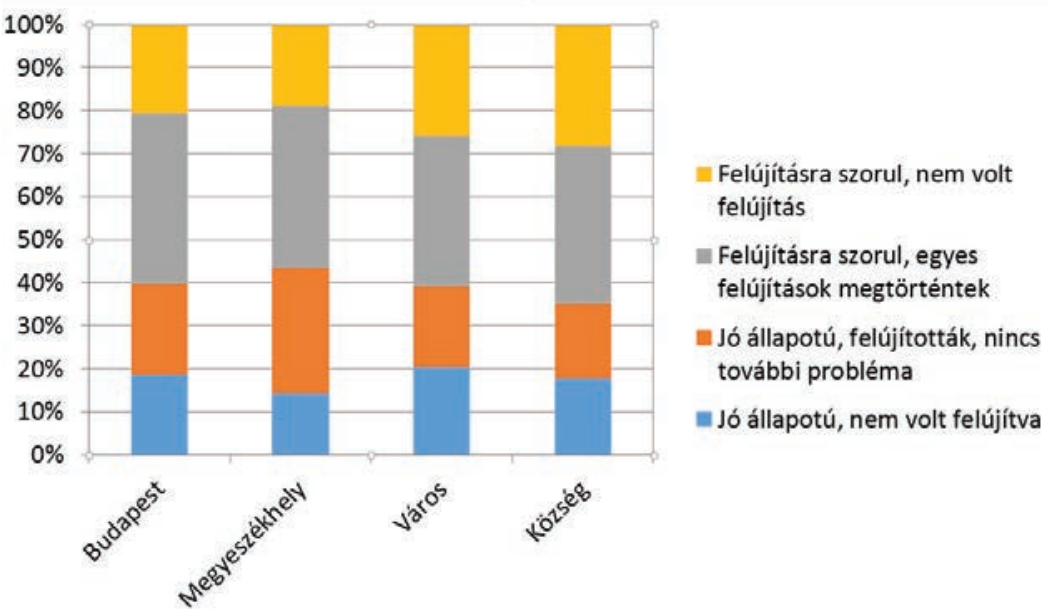

Forrás: KSH 
A leginkább elterjedt épületfajtát, az egyszintes családi házakat összességében átlag alatti minőség, ugyanakkor nagyfokú heterogenitás jellemzi. Ezekben az épületekben a minőségi problémák előfordulása a települési hierarchia mentén lefelé haladva gyakoribbá válik: Budapesten 48, míg a községekben mindössze 35 százalékuk kifogástalan állapotú. Megfordul azonban a sorrend a lakótelepi épületek között, ahol a budapesti épületek minősége kissé elmarad a vidéki városokétól. Az elmúlt évek kiterjedt lakótelepi felújításai ellenére e lakásoknak kevesebb mint 40 százaléka problémamentes, ami azt jelzi, hogy a felújítások általában nem oldották meg az épületek valamennyi fennálló problémáját.

A KSH magyarországi lakáskörülmények széles körü feltárását és megismertetését célzó lakásfelmérésének eredményei a lakók személyes megítélésén alapulnak, és így nem függetlenek a megkérdezettek elvárásaitól és tájékozottságuktól. Az egyes épületminőségi problémákkal kapcsolatban a KSH kérdésére a lakók kiugró számban említették meg az épületek hőszigetelésével összefüggő hiányosságokat, a válaszadók többsége (38\%) szerint a falak külső hőszigetelésére, tatarozására lenne szükség. A nyílászárók cseréjét a megkérdezettek közel harmada (32\%) látta indokoltnak, 29 százalékuk pedig a tető, födém hőszigetelését, cseréjét, illetve javítását említette. Az említések gyakoriságát tekintve ezeket a fütéskorszerüsítésre, illetve a fütési rendszer átalakítására vonatkozó igények követték, a lakások mintegy 11 százalékában. Viszonylag gyakori volt a padló, pince, lábazat szigetelése (9\%), a vezetékcsere (8\%) és a kéménycsere vagy -felújitás (7\%) megjelölése a kérdőívösszesen 19 válaszlehetőséget tartalmazó listáján.

\section{Az elmúlt évek emelkedő kárgyakoriságában közrejátszik az egyre gyakrabban előforduló szélsőséges időjárás is.}

A biztosítók a kártapasztalataik alapján feltehetően más rangsort határoznának meg a lakóépületek szükséges és indokolt felújitásairól. Miközben a lakóknak csupán 8 százaléka említette a vezetékcserét szükséges felújításként, a lakossági vagyonbiztosítási károk között a biztosítók tapasztalatai szerint gyakoriság tekintetében évek óta a vezető károkok között van a vezetékes vízkár (csőtöréskár), valamint annak következménykárai. Ezek különösen a többlakásos lakóépületekben gyakori károk az egyéb kártípus darabszámokhoz képest, ezek között is különösen a lakótelepek házgyári épületeiben, ahol a 30-40 éves vezetékek élettartama már rég túl van az építéskor tervezetten. A társasházak anyagi lehetőségei azonban ritkán teszik lehetővé a régi, elavult vezetékrendszerek teljes cseréjét, és az elmúlt évtized pályázatai is elsősorban az energetikai felújításokra koncentráltak. A vezetékrendszer komplex, egy ütemben történő felújítása lenne a kívánatos, és nyújtana hosszú távú megoldást a rendszeresen bekövetkező csőtörések megelőzésére. Bár a gépészeti vezetékek rejtett szerkezetként kevésbé vannak szem előtt, mint egy rosszállapotú homlokzat, de cseréjük épp a kockázatcsökkentés révén növelni tudja az ingatlan értékét is.

Az elmúlt évek emelkedő kárgyakoriságában közrejátszik az egyre gyakrabban előforduló szélsőséges időjárás is. A klímaváltozás hatásait a magyar lakásbiztosítási piacra részletesen elemezte Pandurics Anett-Szalai Péter-Tóth Krisztián cikke (Biztosítás és Kockázat III. évf. 4. szám), amelynek csak visszautalnék a következtetéseire. Mind az elemi károk, mind az egyéb károk, mint például a csőtörés- vagy beázáskárok növekvő kockázata a lakásbiztosítási díjak emelkedését hordozzák magukban. A jelentős területi eltérések - akár az épületállomány minősége, akár az éghajlati hatás miatti változások eredményeként - a penetrációs potenciál csökkenését hozhatják magukkal a veszélyközösség inhomogenitásának kockázata miatt.

A kárgyakoriság emelkedése azonban nem feltétlenül csak az előzőekben említett okok következménye. Hozzájárult az is, hogy a lakásbiztosítási termékeken keresztül elérhető kiegészítö biztosítások és szolgáltatások száma jelentősen megnövekedett, a lakásbiztosítások rendkívül összetett termékké váltak az elmúlt évtizedben.

\section{Személyre szabható vagy egyszerü termékek?}

A lakásbiztosítások hagyományosan összevont, több kockázatra fedezetet nyúitó, per risk típusú biztosítások. Ma Magyarországon 15 biztosító közel 40 lakásbiztosítási terméket kínál. A biztosítók állományában lévő különböző módozatok száma a nyolcvanat is meghaladja. A tűz- és elemi kár kockázatok mellett már a legegyszerűbb biztosítások is fedezetet nyúitanak csőtörés-, betöréses lopás- vagy üvegtörés károkra is, és ezek mellé a legkülönbözőbb kiegészitő biztosításokat kínálják a biztosítók. A legrégebb óta választható kiegészítő felelősség- és balesetbiztosítás fedezeteken kívül az újabb és újabb termékfejlesztésekkel eloálló, egymással versengő biztosítók termékeiben az épületekre és/vagy ingóságokra fedezetet nyújtó kockázatok mellé bekerültek kockázati élet- és egészségbiztosítási fedezetek, temetésbiztosítás, garanciabiztosítás jellegű fedezetek, jogvédelem-biztosítás, kisállat-biztosítás, és gyakoriak a gépjárművekre megköthető kiegészítők is. Az utóbbi években elterjedtté váltak a kár esetén azonnali vészelhárítást nyúitó assistance szolgáltatások is. Egyre több biztosító kínál all risks típusú vagyonbiztosítást is a hagyományos lakásbiztosítás alternatívájaként a lakossági ügyfelek számára. Ez a sokszínűség segíti a piaci versenyt, de ugyanakkor az ügyfelek számára egyre nehezebbé is teszi a különböző biztosítási feltételek összehasonlítását.

\section{A lakásbiztosításokban még nem sikeruilt igazán áttörést elérnie az online értékesítésnek.}

A Mabisz 2013. március 26-án léptette hatályba a Lakásbiztosítási Standard Termékvázlat alkalmazásának szabályzatát. A Standard Termékvázlat célja, hogy a lakásbiztosítási terméket kereső vagy azzal rendelkező fogyasztók számára transzparens, összehasonlítható legyen a részt vevő társaságok termékválasztéka, ezáltal is erősítve az ügyfélközpontú működést. A Mabisz honlapján szerepelnek azok a lakásbiztosítási termékek is, melyek már a Standard Termékvázlat alkalmazásával készültek

Pontos adatok nem állnak rendelkezésre arra vonatkozóan, hogy a lakásbiztosítások értékesítése hogyan oszlik meg Magyarországon az egyes csatornák között, de a személyes 
kapcsolattal értékesítő csatornák (például belső hálózat, bankfiók) fontosságára utal, hogy azoknak a társaságoknak magas a piaci részaránya, amelyeknél ezek a csatornák erősebbek. Pedig a biztosítótársaságok komoly fejlesztéseket fordítottak az online csatornájuk erősítésére, a lakásbiztosítások többsége megvásárolható online. Ennek ellenére a lakásbiztosításokban szemben például a hasonlóan lakossági szegmenst megcélzó gépjármű-biztosításokkal - még nem sikerült igazán áttörést elérnie az online értékesítésnek. A különböző ügyfélkutatások azt mutatják, hogy terjed az online tájékozódók aránya, különösen a városi, fiatalabb korosztályban. Azonban még az online világban otthonosan mozgók is gyakran igénylik a személyes tanácsadást egy lakásbiztosítási szerződés megkötéséhez. Ebben valószínűleg közrejátszik ezeknek a termékeknek az összetettsége is. Valójában egy ellentmondásos kihívásnak kellene megfelelniük a lakásbiztosítási termékeknek, amikor az ügyfelek elvárása szerint egyszerre kellene személyre szabhatónak és ugyanakkor egyszerünek lenniük. A biztositók folyamatosan keresik a megoldást erre a kihívásra többek között az online kínált termékeik egyszerüsítésével, az elöre definiált fedezeti körű termékcsomagok összeállitásával, az értékesítési felület grafikus elemekkel támogatott egyszerüsítésével.

Az ügyfelek különböző élethelyzeteihez kialakított kiegészítő biztosítások a személyre szabhatóságot szolgálják, de sok esetben épp a kiegészítő biztosítások sokfélesége bizonytalanítja el az ügyfelet, és irányítja - az online tájékozódást követően - személyes csatornára szerződést kötni. Az online értékesítésben a technológiai fejlődés hozhat áttörést. A mesterséges intellingencia integrálása a felhasználói felületekbe (pl. mobil telefonos alkalmazások, chat felületek) lehetővé teheti a komplex termékekkel kapcsolatos azonnali, egyszerü tanácsadást, a gyorsabb kiszolgálást és a jobb ügyfélélményt.

\section{Okos otthon, okos otthonbiztosítás}

Nem feledkezhetünk meg a biztosítók előtti kihívások vizsgálatakor a digitalizációra és az insurtech jelenségre való kitekintésről sem. Bár ezek a kérdések az egész biztositási szektortérintik, és nem lakásbiztosítás-specifikusak, azonban az évek óta változatlan, alacsony szintü átlagdíj, az erős költségnyomás, valamint a munkaigényes bagatellkárok nagy aránya mind azt valószínűsíti, hogy a lakossági vagyon terület az egyik, ahol elsők között lehet tere az új innovatív megoldásoknak. A biztositóknak meg kell találniuk a megoldást arra, hogy könnyen megérthetö, az ügyfelek igényeit kiszolgáló szolgáltatást kínáljanak, ami nem egyszerű feladat egy olyan területen, ahol az ügyfélkapcsolat alacsony frekvenciájú, sőt, előfordulhat, hogy biztosítási szolgáltatással nem is találkozik az ügyfél, ha a szerződés tartama alatt nem következik be biztosítási esemény. Nincs azonban sok idejük a hazai biztosítóknak, mivel külföldön már megjelentek az első, szektoron kívülről érkező kihívók, akik új szemléletet hoztak nemcsak a biztosítási termékfejlesztésben, hanem az értékesítés és a kárrendezés területein is. 2016-ban az USA-ban berobbant Lemonade az IT területről érkezve támadja saját pályájukon a hagyományos biztosítókat. A chatbotokat és AI-t használó társaság nemcsak az értékesitését automatizálta, hanem a kárrendezését is a mesterséges intelligenciára és az online kiszolgálásra alapozza.
A legtöbb online értékesítési felületen már most is segítséget kérhet a kötés során elbizonytalanodó ügyfél visszahíváskérés, chat vagy video chat formájában az ügyfélszolgálat nyitvatartási idejében. Megállíthatatlannak tünik azonban a chatbotok terjedése a biztosítási szektorban is, ahogy más területeken az ügyfélszolgálatot müködtető szolgáltató vállalatok közül már nem egy müködtet ilyen programot, amellyel a fogyasztó a nap bármely órájában chatet kezdeményezhet. Az ügyfél úgy érezheti, mintha egy másik emberrel csevegne az elektronikus felületen, miközben a válaszokat egy mesterséges intelligencia küldi meg. Ez a technológia fellendítheti az online értékesítést, és hatékonyságnövelő lehet az ügyfélkiszolgálás más területein - mint a szerződéskezelés, kárbejelentés, kárrendezés - is. A chatbotok már a hazánkban is megjelentek, chatelhetünk például az Árkád, a Sziget, az Index botjaival, és az idei év első felében várható az első hazai banki chatbot megjelenése is. Így valószínűleg nincs messze az az idő sem, amikor a biztosítók online ügyfélszolgálati felületein is robotok válaszolják meg az ügyfelek leggyakoribb rutinkérdéseit.

A digitális világ másik fontos trendje a „Big Data” fogalomhoz kapcsolódó adatbányászat. Az ebben rejlő lehetőségek kiaknázásához megfelelő adattisztaságra van szükség, amit a lakossági vagyonbiztosítások esetében nehezít, hogy ezeknek a biztosításoknak egyik fö paramétere a biztosított vagyontárgyhoz kötődő kockázatviselési hely, azaz az ingatlan címe. Magyarországon hiányzik egy olyan egyértelmű címazonosításra és validációra használható nyilvános adatbázis, amely a címek rögzítésének egységességét támogatná. A címek azonosítása sok esetben már közterület szinten sem egyszerü, az ügyfél által megadott adatok változatos módon lehetnek nyilvántartva a biztosítók rendszereiben (pl.: Petőfi utca, Petőfi S. u., Petőfi Sándor utca stb.), ami nehezíti az adatok összekapcsolását. A házszámok és a házszám szint alatti címadatok pedig további variációkra adnak lehetőséget. Előfordult, hogy a szerződő vagy épp az értékesítő volt ellenérdekelt a pontos címadat megadásában. A biztosítók az új kötéseknél néhány éve már bevezették a közterülettörzsön alapuló címrögzítést, azonban a régi, sok esetben még papíron megkötött szerződésállomány címeinek tisztítása nehezen automatizálható, lassú folyamat, ami nehezíti a Big Data elemzéseket. A közterülettörzs mellett a GPS koordináta alapú címmeghatározás lehet a másik lehetőség az ingatlan pontos azonosításához, melynek rögzítését a külső adatbázisok mellett az ügynökök, kockázatfelmérők, kárszakértők által használt mobileszközökben megtalálható helymeghatározó szolgáltatás is támogatni tudja. A régi szerződésállományra vonatkozóan azonban még így is csak lassan várható az adatok tisztítása, ami az adatbányászat lehetőségeit szűkíti, lassítja.

A lakásbiztosításokkal kapcsolatos innovációk felsorolásakor meg kell említeniazún. Smart Home megoldásokat is. Az otthonok automatizálásának berendezési tárgyai, az IoT eszközök terjedése a lakásbiztosításokban biztosított vagyontárgyak körét fogja bővíteni, és a biztosított értéket növeli. Az új eszközök már nemcsak a vagyon- vagy a tűzvédelmet képesek erősíteni, hanem csökkenthetik a biztositók más kockázatait is. Így például a csőtöréskárok koraiészlelésére már többféle megoldás megjelent, amely azon túl, hogy figyelmezteti az ügyfelet, ha bármi gond jelentkezik az otthonában, akár a vezetékrendszer elzáró csapjával is összeköthető. Így a kiömlő víz észlelése esetén azonnal be is tud avatkozni, megakadályozva egy nagyobb kár bekövetkezé- 
sét, sőt, az ügyfél értesítése mellett jelzést indíthat a biztosító felé is, hogy assistance szolgáltatási igény merült fel. Az okos otthon megoldások előnyei mellett azonban ezek az eszközök nem elhanyagolható kockázatot is jelentenek. Hiszen a hálózatra kötött eszközökön keresztül úifajta támadásnak is kitesszük otthonunkat, egy betörő a rendszert feltörve információt szerezhet arról, mikor nem vagyunk otthon, kinyithatja a zárat, és nyom nélkül szerezheti meg értékeinket. A biztosítási termékfejlesztések során ezeket a kockázatokat is mérlegelniük kell a biztosítóknak. A válasz feltehetően a jelenlegi vagyonvédelmi eszközökre vonatkozó ajánlási rendszer kibővítése lesz, de nincsenek könnyü helyzetben a biztosítók, amikor azt kell meghatározniuk, mi az elvárható szintű védelem az IT technológiában egy lakossági fogyasztótól, és hogyan ellenőrizhető kár esetén, hogy a felhőben tárolt adatokat feltörték, meghamisították-e.

\section{A Smart Home megoldások elterjedése feltehetően \\ lassabban megy majd végbe, mint az IoT \\ eszközök beépüilése a mindennapjainkba.}

A Smart Home megoldások elterjedése feltehetően lassabban megy majd végbe, mint az IoT eszközök beépülése a mindennapjainkba. Bár a piacon már kaphatók megfizethető árú eszközök, azonban az elterjedésüknek még van néhány gátja. Az egyik ilyen akadály, hogy az épület átalakítása nagyobb beruházást igényel, hiszen az elektromos hálózat teljes átalakítása is szükséges lehet, hogy az eszközök az ügyfél igényeit kiszolgáló alhálózatokban legyenek összekapcsolva. Léteznek persze nagyobb átalakítás nélkül, önmagukban is használható eszközök, pl. okos villanykörték, termosztátok, azonban egy távolról vezérelhető otthoni világítás önmagában nem elég vonzó a felhasználó részére széles körű elterjedéshez. Az okos otthonokba belépni vágyó iparágaknak - ilyenek a biztosítók mellett az okos készülékek gyártói, a szolgáltatók, biztonságtechnikai vállalatok - meg kell találniuk, milyen felhasználói élményt tudnak kínálni, milyen szolgáltatásokkal tudják eléggé vonzóvá tenni az eszközeiket ahhoz, hogy az ügyfelek beépítsék azokat otthonaikba, és megosszák a privát szférájuk adatait velük. Hogy ez mennyire nem egyszerü feladat, azt jól szemlélteti a „The Digital Future of Insurance" konferencián bemutatott amerikai példa. Egy manhattani luxuslakást biztosító kiemelt ügyfél millió dolláros vízkárát követően a biztosító felajánlotta, hogy a kár helyreállítása során díjmentesen telepít számára egy szivárgásérzékelő technológiát. A friss kártapasztalat ellenére az ügyfél megtiltotta az eszköz beszerelését. Csupán az ügyfelek 26 százaléka fogadta el a hasonló ajánlatukat. Ennek a fajta bizalmatlanságnak a leküzdése jelenti az egyik nagy kihívást a biztosítók és a Smart Home iparághoz kapcsolódó többi szereplő számára.

A biztositások területén hamarabb épülhetnek be a digitalizált megoldások a lakossági vagyonbiztosítások szolgáltatási oldalába, mint a termékekbe vagy akár az értékesítésbe. Ma már minden technológiai eszköz adott ahhoz, hogy a biztosítók távolról végezzék el a szerződéskötéshez szükséges szemlét vagy akár egy kár felmérését. Az ügyfelek zsebében ott vannak azok a mobiltelefonok, amelyeknek a kamerája már megfelelő minőségü fotókat, felvételeket tud készíteni ahhoz, hogy a biztosító szakértője akár az irodából, akár otthon az íróasztalánál ülve végezze el egy telefonos applikáción keresztül az ügyfél segítségével a szemlét. Ezzel a megoldással a szolgáltatás gyorsab- bá válhat, és az ügyfél elégedettségét fokozhatja a szolgáltatás időbeli rugalmassága is. Bár ezek a megoldások a nem jó szándékú ügyfelek számára is vonzóak lehetnek a visszaélések könnyebb lehetősége miatt, de megfelelő ellenőrzések beépítésével csökkenthető a fraud-kockázat.

\section{Összegzés}

A piaci környezet, az épületállomány minőségéből fakadó kockázatok és a felgyorsuló technológiai fejlődések egyaránt kihívásokat támasztanak a lakásbiztosításokkal foglalkozó társaságokkal szemben. Ezek a kihívások azonban nemcsak feladatokat jelentenek, hanem új lehetőségeket is. A biztosítási termékek új generációja fejlődhet ki, amely termékekben egyes - ma még általánosnak számító - fedezetek indokolatlanná válnak, ugyanakkor egészen új kockázati körök is bekerülhetnek a biztosításba, megváltozhat a lakástermékek ma megszokott felépítése, jellegzetességei is. Az új biztosítási termékeket már nem lehet hosszú évekre tervezni, a gyorsuló világban gyakrabban lesz szükség a termékek frissítésére, módosítására. Ehhez megfelelően rugalmas, moduláris termékstruktúrát kell kidolgozniuk a társaságoknak, amelybe könnyen integrálhatóak a lakásokban megjelenő új technológiák miatti új kockázatok. Ugyanakkor arról sem szabad elfeledkezni, hogy az új technológiák terjedése a közeljövőben csak egy szűk ügyfélkörben várható. Amint a magyarországi lakásállomány-felmérés bemutatta, az épületek nagy részénél műszakilag jóval fontosabb felújítások lennének szükségesek, mint az „Okos Otthonná” alakítás. Ezeknek az épületeknek a biztosítására a meglévő termékek megfelelő kockázatokat kínálnak, azonban mind fontosabbá válik a veszélyközösség védelme érdekében a szegmentált árazás és az automatizált kockázatvállalás.

Fontos feladat a biztosítók számára a meglévő adatállományuk feldolgozása, tisztítása, mert ezek elemzése támogatja az ügyfelek igényeinek megértését, a pontosabb szegmentálást, és támpontot nyújt a fejlesztési irányok meghatározásában.

\section{IRODALOMJEGYZEKK}

Digital Insurance
https://www.dig-in.com/news/talking-ai-sharing-economy-and-smart-homes-at-dig-in

Letöltés: 2017.05.13.

KSH: Miben élünk? A 2015. évi lakásfelmérés főbb eredményei, 2016. augusztus

http://www.ksh.hu/docs/hun/xftp/idoszaki/pdf/miben_elunk15.pdf

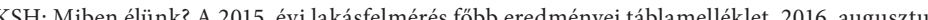

http://www.ksh.hu/docs/hun/xtp/idoszaki/pdf/miben_elunk15.xls

Letöltés: 2017.05.15

KSH: Lakásépités, lakásmegszünés, üdülóépités (2001-2016) Frissitve: 2017.02.24.

http:///www.ksh.hu/docs/hun/xstadat//xstadat_eves/__zrs001.htm

Letöltés: 2017.03 .16

https://www.otpbank.hu/OTP_ZZB/file/OTP_Lakoingatlan_Ertekterkep_2016_2.pdf

Letöltés: 2017.03.16.

Pandurics Anett - Szalai Péter - Tóth Krisztián: A klímaváltozás hatása a magyar biztosittás piacra (Biztositásés Kockázat III.évf. 4. szám) Társaság a Lakásépítésért, Lakásfelújittásért Egyesület, OTTHONTEREMTES 2015. Lakásépitések, lakásfelújitások Magyarországo Budapest, 2015. ápril

htt:://www.igylakunk.hu/otthonteremtes2015/otthonteremtes_2015 pd 